\title{
Effect of Mobile Banking and Online Shopping on Consumer Behavior
}

\author{
Mamik Nur Farida1, Waspodo Tjipto Subroto ${ }^{2}$
}

\section{ARTICLE INFO}

Article History:

Received 05.10.2018

Received in revised form

28.12.2018

Accepted

Available online

01.04.2019

\begin{abstract}
The development of information technology is used in various sectors including the banking sector and shopping media. This study aims to determine the effect of mobile banking and online shopping on consumer behavior of students of the economics faculty of Universitas Negeri Surabaya. The number of research samples is 102 students who have used mobile banking and online shopping services. This study is a type of explanatory research that use a quantitative approach. The hypothesis test used is multiple linear reg ression and F-test. Based on the results of the regression test, it can be concluded that mobile banking has a significant positive effect on co nsumer behavior and online shopping also has a signific ant positive effect on consumer behavior. From the results of the F-test, it can be concluded that mobile banking and online shopping have a joint effect on consumer behavior by $47.6 \%$, while the remaining $52.4 \%$ is influenced by other variables.
\end{abstract}

(C) IJERE. All rights reserved

Keywords:

Mobile banking, online shopping, consumer behavior

\section{INTRODUCTION}

Technology growth in the current era of globalization is very fast in innovating. Progress in technology will make it easier for humans to do all their activities. One of the technological advances is in the field of information. The fastest and dominant development of information technology is the internet. The development of the internet is currently used in various sectors. The survey results conducted by the Indonesian Internet User Services Association (APJII) by region show that Java Island is in the top position in the use of the internet with a total of $58.08 \%$ of all internet users in Indonesia, which is 86.21 million (APJII 2017).

One sector that also utilizes the development of internet information technology is the banking sector. The bank provides freedom in serving customers with self-service that facilitates customers in making transactions. Current banking services must be able to adjust to the mobility of consumers, so we need a supporting device called advice mobile. One application that has become a concern now is mobile banking. Mobile banking or commonly called M-banking is a banking service provided by banks to support the smoothness and ease of banking activities and the effectiveness and efficiency of customers to carry out various transactions (Wulandari et al. 2017). Today's modern society tends to use devices mobile to support their needs, such as purchase or payment transactions and search for product information online.

The development of internet technology is not only one of the information media for communication, but also shopping media online called online shopping. The rapid development of the digital age of the internet has made many business people turn to businesses online that make consumers interested in shopping online. The benefit of online shopping that can be felt by consumers is being able to choose the desired goods or services for 24 hours without time and for consumers who are located far enough from the location do not need to come directly to buy the desired item. This will certainly save time and money. Moreover, the presence of mobile banking makes it easier to make payment transactions (Wulandari et al. 2017).

${ }^{1}$ Corresponding e-mail: mamik.18005@mhs.unesa.ac.id, orcid.org/0000-0002-7617-9946 Universitas Negeri Surabaya' ${ }^{1}$ Universitas Negeri Surabaya² 2

waspodosubroto@unesa.ac.id; orcid.org/0000-0002-1477-1653 
As consumers should be more careful in transactions, online shopping such as adjusting the income, comparing the level of product quality, good looking product features, choose the price, easy payment, and service services online such as the delivery of the product. Furthermore, consumers evaluate alternatives and choose the one that best fits their criteria to meet perceived needs, not just $w$ ants. Thus the attitude of shopping online can refer to the psychological state of consumers in terms of making purchases on the internet (Hossein, et al. 2012). Because consumer behavior can be a benchmark in influencing the selection and decision to buy goods and services (Ko, et al, 2004).

Behavior is the response or reaction of individuals to stimuli or the environment. The theory of consumer behavior explains the process of consumer action which is influenced by something to produce some output. How ard and Shet (1967) explained that the theory of consumer behavior can be seen from the process, namely input in the form of marketing stimuli and the environment that will produce output in the form of attitudes tow ard behavior (attitudes), intention (interest), and purchase behavior (Suhari, 2010).

The results of the Firdauzi (2016) study explain that financial ability, consumer behavior, and convenience have a significant positive effect on the interest in using electronic money. Consumer satisfaction when transacting influences consumer confidence in shaping attitudes and behavior to repurchase e-commerce (Sidharta and Suzanto, 2015).

Ease of online financial transactions and purchases online makes researchers want to conduct research to determine the effect of mobile banking and online shopping on consumer behavior with the goal of the study was students of economic faculties Universitas Negeri Surabaya.

\section{Mobile Banking}

Various service product offers issued by banks in easy access by banks to customers, one of which is using mobile banking. Mobile banking is one part of e-banking which is the banking information via wireless most recent services offered by the bank with use technology mobile phone to support smooth and easy activities banking (Wulandari, et al. 2017). Customers who use mobile banking no longer need to go to an ATM or to a bank for do banking transactions such as transferring money, checking balances, or paying bills (except cash withdrawals). ease in obtaining financial information and conducting transactions online is important for customers, especially for those who have a high level of mobility. Excellence Another of aspect mobile banking is the security user-ID that not everyone can find out about except the owner. Based on the advantages possessed by the mobile banking, the party banks believe they can attract customers by providing similar services. Mobile banking generally provides functions Informational (informational), Communicative (communicative), and Transactional (can make transactions) (Wulandari, et al. 2017).

Even though all the benefits available are many, there are still few customers who use mobile banking. In Indonesia it has an interesting phenomenon regarding mobile banking this. Based on data from the Indonesian Telecommunications Regulatory Agency (BRTI), it is estimated that the growth of subscribers of the SIM (card Subscriber Identification Module) in early 2018 is estimated to reach 367 million customers. How ever, the number of customers adopting services mobile banking is only around less than half the number of mobile subscribers (katadata-2018). This phenomenon is influenced by several factors, one of which is because customers already feel comfortable with existing services (Rayana, 2018).

\section{Online Shopping}

Shopping online also called online shopping is the activity of purchasing goods and services via the Internet. Through online shopping a buyers can see first goods and services to be purchased through the web or application promoted by seller. This activity online shopping is a market with forms communication new that not need communication look at advance in a manner directly, but 
could do in a manner separate from and to all over world through media notebooks, computers, or hand phones that are connected to service access Internet (Teguh, 2012).

There are several media shopping online, namely blogs, websites, networking sites social, and applications that can be installed on mobile phones. First, blogs, are services the web where my business is online use a blog as a store online to sell at once promote goods and services offered to prospective buyers. Secondly, there are many websites the current web that provides shopping services online both local and international web. Usually there is a basket shopping, prospective buyers can choose the product to be purchased. Besides shopping carts, buyers too can contact the seller directly direct transactions can be made through telephone or email as done by shop building services online. Third, social networking sites. The rise of site growth social networks in the world, media social netw orking is also glimpsed by shoppers online to market their products. The seller will upload the items offered then distributed via messaging or features photo sharing. This form of offering is a development of catalog media that w as previously distributed in the form of print media per month, now distributed through media online catalogs whose offerings can be updated at any time. Fourth, shopping applications online that can be directly installed on mobile phones, make it easier for consumers to directly access without having to open the web first. Many online shopping applications are available by offering various kinds of promos or discounts when shopping using the application (Adityo, 2011).

There are eight factors that influence the the decision to do an online shopping: e-service quality, time, price, easiness, security, trust, convenience, and website quality. How ever, after the rotation there are 3 groups, each group had the most dominant factors, namely: the trust factor, price factor and time factor (Edwar, et al, 2018).

\section{Consumer Behavior Consumers}

Consumers are very important people for an entrepreneur because they are able to develop a business. Whatever behavior is owned by a consumer, an entrepreneur will usually give in and serve these consumers so that a satisfying buying process occurs. The behavior of each consumer can be different because of things that influence. Both the influence of the consumer itself and the influence from outside (Hossein, et al. 2012).

According to John C. Mowen and Michael Minor defines consumer behavior as a study of buying units and exchange processes that involve the acquisition of various products, services and experiences and ideas. According to Lamb, Hair and Mc. Daniel stated that consumer behavior is the process of a customer in making a decision to buy, use and consume goods and services purchased, also including factors that influence the decision to buy and use products. According to Engel, Blackwell and Miniard, states that consumer behavior is an action that is directly involved in acquiring, consuming and spending products and services including the decision process that precedes and follows this action (Rangkuti, 2002).

Whether we realize it or not a person's behavior as a consumer has changed with the development of technology. The development of internet technology that fills human life makes us move from conventional culture to modern habits in various aspects. The internet has now become a communication tool that many people are interested in. The development of technology and information greatly influences the pattern of financial behavior of consumers who want to be all practical and efficient in terms of choosing and consuming products or services. This condition does not rule out the possibility of consumptive behavior (Rangkuti, 2002)..

\section{METHODS}

This study is a type of explanatory research. The research approach used is a quantitative approach because it emphasizes the testing of theory by measuring the research variables numerically 
and analyzing the data with statistical procedures (Indrianto and Supomo, 2002: 12). This research category is included in survey research, namely research that takes samples from the population and uses questionnaires as a means of collecting basic data as measured by the Likert scale (1-5).

\section{Material}

The instrument of data collection is done by giving the question form and questionnaire which is divided on use of mobile banking, online shopping, and consumer behavior . Variable indicators Mobile banking include: technology, usability, convenience, service features, trust, interests, intensity, and risk. Indicators of variables online shopping include: information quality, product quality, service quality, delivery quality, price, cost, intensity, risk, and interest. While the consumer behavior variable indicators include: the usefulness of technology, up to date trends, technological sophistication, effectiveness, hobbies, convenience, choice of alternatives, and needs.

The population used in this study is the economics faculty of Universitas Negeri Surabaya who have used mobile banking and online shopping facilities. The researcher use population in this university because the researcher is currently study postgraduate program in Universitas Negeri Surabaya. The total sample of this study was 102 respondents. The sample criteria are who have mobile banking, even shopping by online, and student of the economics faculty of Universitas Negeri Surabaya including of Islamic economics, economic education, trade system education, office administration, management, and accounting. The sampling method used in this study is based on nonprobability sampling because the magnitude of the opportunity for the element to be selected as the subject of the sample is unknown. The sampling technique in this study was conducted based on sampling purpose based on certain considerations (judgment sampling).

\section{Data Analyses}

For data analyses, SPSS 18.0 Statistical Package Program w as used. The items of mobile banking, online shopping, and consumer behavior were scored as (5) "Totally Agree", (4) "Mostly Agree", (3) "Somewhat Agree", (2) "Partially Agree", and (1) "Disagree". For statistical tests, multiple linear regression analysis is used. Multiple linear regression analysis is an analysis technique commonly used in analyzing relationships and the effect of one dependent variable with two or more independent variables. F-test and analyses of variance were performed in order to investigate whether the scores differed according to the variables. $0.05 \mathrm{w}$ as accepted as the significance level in the research. Systematically, research designs can be described as follows:

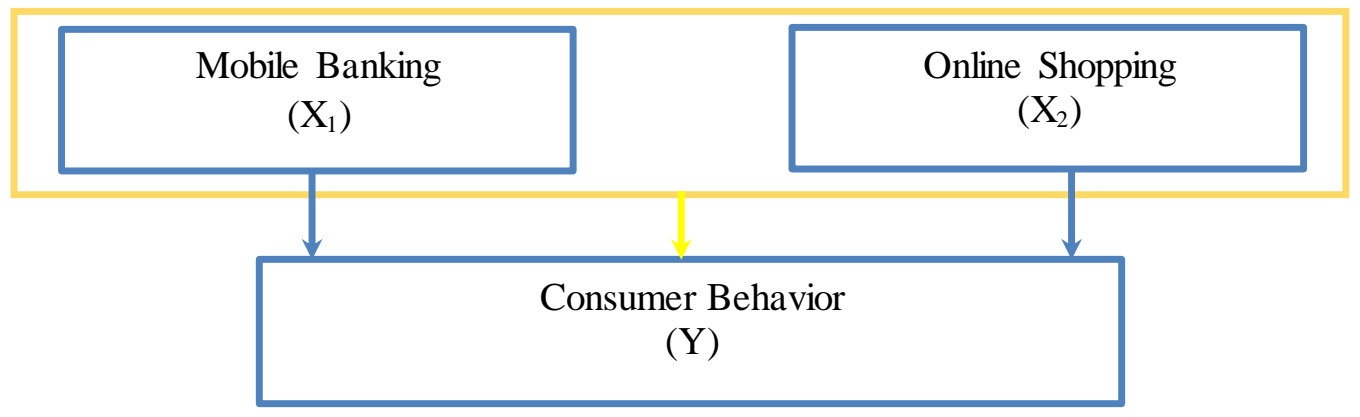

Figure 1. Chart of Research Design 


\section{FINDING}

Test are used to determine the validity of the question items used in the implementation of research. The validity test of all research variables is presented in the following table 1 :

Table 1: Validity test of mobile banking, online shopping, and consumer's behaviors statements

\begin{tabular}{|c|c|c|c|c|}
\hline Variable & Indicators & $\begin{array}{l}\text { Corrected } \\
\text { item-total } \\
\text { correlation }\end{array}$ & Standard & Validation \\
\hline \multirow[t]{8}{*}{ Mobile Banking (X1) } & Statement 1 & 0.7940 & 0.1946 & Valid \\
\hline & Statement 2 & 0.7799 & 0.1946 & Valid \\
\hline & Statement 3 & 0.7828 & 0.1946 & Valid \\
\hline & Statement 4 & 0.8043 & 0.1946 & Valid \\
\hline & Statement 5 & 0.6877 & 0.1946 & Valid \\
\hline & Statement 6 & 0.7920 & 0.1946 & Valid \\
\hline & Statement 7 & 0.7094 & 0.1946 & Valid \\
\hline & Statement 8 & 0.7288 & 0,1946 & Valid \\
\hline \multirow[t]{8}{*}{ Online Shopping (X2) } & Statement 1 & 0.5980 & 0.1946 & Valid \\
\hline & Statement 2 & 0.8000 & 0.1946 & Valid \\
\hline & Statement 3 & 0.6524 & 0.1946 & Valid \\
\hline & Statement 4 & 0.6590 & 0.1946 & Valid \\
\hline & Statement 5 & 0.6462 & 0,1946 & Valid \\
\hline & Statement 6 & 0.7138 & 0.1946 & Valid \\
\hline & Statement 7 & 0.7607 & 0.1946 & Valid \\
\hline & Statement 8 & 0.7421 & 0.1946 & Valid \\
\hline \multirow{8}{*}{$\begin{array}{l}\text { Consumer's Behaviors } \\
\text { (Y) }\end{array}$} & Statement 1 & 0.5662 & 0.1946 & Valid \\
\hline & Statement 2 & 0.5705 & 01946 & Valid \\
\hline & Statement 3 & 0.6615 & 0.1946 & Valid \\
\hline & Statement 4 & 0.6148 & 0.1946 & Valid \\
\hline & Statement 5 & 0.7540 & 0.1946 & Valid \\
\hline & Statement 6 & 0.7892 & 0.1946 & Valid \\
\hline & Statement 7 & 0.7888 & 0.1946 & Valid \\
\hline & Statement 8 & 0.6150 & 0.1946 & Valid \\
\hline
\end{tabular}

The validated total item correlation is compared with the $\mathrm{r}$ table value with a significance of $5 \%$, which is 0.1946 . If the total item correlation coefficient is validated $>0.1946$ then the instrument is considered valid. Based on the results of the validity test, all statements in the questionnaire are valid.

Reability test was performed with Cronbach alpha coefficient on all three variables. This is done to determine the consistency of the test instruments used. Cronbach's alpha coefficient values are explained in the following table 2:

Table 2: Reliability test of of mobile banking, online shopping, and consumer's behaviors

\begin{tabular}{|lc|}
\hline Variables & Cronbach Alpha Value \\
\hline Mobile Banking & 0.8887 \\
\hline Online Shopping & 0.8492 \\
\hline Consumer's Behavior & 0.8283 \\
\hline
\end{tabular}


All Cronbach's alpha values are $>0.7$, so it can be concluded that the instrument tests can be relied upon (Hair et al., 2006).

Linear regression analysis is used to determine the linear relationship of each independent variablebetween mobilebanking and online shopping with the dependent variable namely consumer behavior whether positive or negative and to predict the value of the dependent variable if the value of the independent variable increases or decline.

Table 3: Regression of mobile banking and online shopping on consumer's behaviors

\begin{tabular}{|c|c|c|c|c|c|c|}
\hline & & & cientsa & & & \\
\hline & & & ients & Standardized & $\mathrm{T}$ & Sig. \\
\hline & & B & Std. Error & Beta & & \\
\hline 1 & (Constant) & 6.352 & 2.720 & & 2.336 & 0.022 \\
\hline & Mobile Banking & 0.364 & 0.067 & 0.403 & 5.413 & 0.000 \\
\hline & Online Shopping & 0.458 & 0.070 & 0.483 & 6.493 & 0.000 \\
\hline
\end{tabular}

Above data shows that the significant value to mobile banking is $0.000(\mathrm{p}<0.05)$ means that mobile banking has a significant effect on consumer behavior. Furthermore, for variable online shopping, the data above shows the value of online shopping significan ce of $0,000(p<0.05)$, meaning that online shopping has a significant effect on consumer behavior.

F-test is used to determine the effect of mobile banking and online shopping together on consumer behavior. The results of the F-test analysis are explained in the following:

Table 4: F-Test

\begin{tabular}{|c|c|c|c|c|c|c|}
\hline \multicolumn{7}{|c|}{ ANOVA $^{b}$} \\
\hline \multicolumn{2}{|c|}{ Model } & $\begin{array}{l}\text { Sum of } \\
\text { Squares }\end{array}$ & Df & $\begin{array}{l}\text { Mean } \\
\text { Square }\end{array}$ & $\mathrm{F}$ & Sig. \\
\hline \multirow{3}{*}{1} & Regression & 900,328 & 2 & 450.164 & 45,022 & $0,000^{\mathrm{a}}$ \\
\hline & Residual & 989,878 & 99 & 9,999 & & \\
\hline & Total & 1890,206 & 101 & & & \\
\hline \multicolumn{7}{|c|}{ a. Predictors:(Constant), Online Shopping, Mobile Banking } \\
\hline \multicolumn{7}{|c|}{ b. Dependent Variable: Consumer Behavior } \\
\hline \multicolumn{7}{|c|}{ c. $\mathrm{R}^{2}=0.476, \mathrm{~N}=102$} \\
\hline
\end{tabular}

Based on the data above, the significance value of $\mathrm{F}$ is $0.000(\mathrm{p}<0.05)$, it can be concluded that the variables of mobile banking and online shopping have a significant effect on consumer behavior. $R^{2}$ value is 0.476 which shows that mobile banking and online shopping affect consumer behavior by $47.6 \%$. While the remaining $52.4 \%$ is influenced by other variables.

\section{RESULT, DISCUSSION, AND SUGGESTIONS}

This research aims to examine the effects of mobile banking and online shopping on consumers behavior specially student of economic faculties in Universitas Negeri Surabaya. In addition, it also checks whether there are effects between mobile banking on consumer behavior, the effect of online shopping on consumer behavior, and the effects of mobile banking and shared online shopping on consumer behavior. Based on the results of research and discussion conducted by researchers, it can be concluded from multiple linear regression analysis that the significant value for mobile banking 
has a significant influence on consumer behavior. Furthermore, for variable online shopping, the data shows the significance value of online shopping has a significant influence on consumer behavior. Whereas from the F-test mobile banking and online shopping together have a significant positive influence on consumer behavior by $47.6 \%$, while the remaining $52.4 \%$ is influenced by other variables. Some researches support this finding are the results of the Firdauzi (2016) study explain that financial ability, consumer behavior, and convenience have a significant positive effect on the interest in using electronic money. Consumer satisfaction when transacting influences consumer confidence in shaping attitudes and behavior to repurchase e-commerce (Sidharta and Suzanto, 2015). Whereas results contradict with some other study by Dwimastia Harlan (2014) that there is a negative influence and significant perceived risk to interest Transaction Using E-Banking on UMKM in the City of Yogyakarta. As students of economic faculties, they should be able to keep up with technological advances by utilizing mobile banking facilities for ease of transactions, especially the current online shopping transactions.

This study has limitations including the number of samples studied is relatively small, limited only to students of the economics faculty of Universitas Negeri Surabaya. Further research must be carried out in a higher context. Only a small number of students from the Surabaya Faculty of Economics take advantage of the sophistication of mobile banking technology, so financial literacy and the implementation of mobile banking are needed for students, especially economic students.

\section{REFERENCES}

Adityo, B. (2011). Analysis of the effect of trust, ease and quality of information on purchase decisions online on the kaskus site.

Ayu, I. \& Upadianti,A. (2018). The role of trust mediates risk perception of intention to use mandiri mobile banking in denpasar city. E-Jurnal Manajemen Unud, 7(5): 2621-51.

Consultant, Duwi. (2011). Analysis of multiple linear regression.accessed November 20, 2018 from http://duwiconsultant.blogspot.com/2011/11/regresi-berganda.html

Saputrı ,D.Y., Rurukayah , Indriayu,M. (2018). Need assessment of interactive multimedia based on game in elementary school: A challenge into learning in 21st century. International Journal of Educational Research Review, 3(3), 1-8

Edwar,M., Diansari,R.A.A. \& Winaw ati,N.F. (2018).The factors that affecting the product purchasing decision through online shopping by students of Surabay a state university. International Journal of Educational Research Review, 3(4), 54-64.

Fatimah, Nur and Susanti. (2018). the effect of financial accounting learning, financial literacy, and financial income of students of the faculty of economics, University of Muhammadiyah Gresik. Accounting Education Journal, 6(1), 48-57.

Fita, S. (2018). Fintech's penetration to financing: Threats or opportunities for banking? Accessed November 20, 2018 from https://katadata.co.id/telaah/2018/11/19/penetrasi-fintech-kepembanaan-ancaman-atau-peluang - for banks

MoshrefJavadi,H.M., Dolatabadi,H.R., Nourbakhsh,M. \& Poursaeedi,A. (2012). Analysis of factors affecting on online shopping behavior of consumers. International Journal of Marketing Studies, 4 (5), 81-98.

Jayasuriya, Nisha Anupama \& SM Ferdous Azam. (2017). The impact of social media marketing on brand equity: A study of fashion -wear retail in Sri Lanka. International Review of Management and 
Marketing, 7 (5): 178-83.

Khomalasari, Devi Ida.Influence of Benefit Perception, Perception of Ease of Use on the Use of Mobile Banking Services Through Attitude as Interviening.

Krishanan, D., Khin,A.A., Low,K., Teng,L. \& Chinna,K. (2016). Consumers' perceived interactivity and intention to use mobile banking in structural equation modeling. International Review of Management and Marketing, 6 (4): 883-90.

Lin, H-M. (2011). Taiwanese consumers' internet decision-making styles: The role of perceptions of the Internet. International Review of Management and Marketing,1(4): 86-92.

Matic, Matea and Katija Vojvodic. (2014). "Customer-Perceived Insecurity of Online Shopping Environment." International Review of Management and Marketing, 4 (1): 59-65.

Raharjo, S.(2018). Perform Statistical Data with SPSS". Accessed November 20, 2018 from https://www.spssindonesia.com

Rayana, U. (2018). Comparing operator customers before and after prepaid re-registration. Accessed November 20, 2018 from https://selular.id/2018/03/

Sidharta, I. \& Suzanto,B. (2015). The Influence of Satisfaction of Online Shopping Transactions and Consumer Trust in Consumer Attitudes and Behavior in E-Commerce. 9 (1): 23-36.

Susanti, A. (2015). Effect of Usage Perception, Perception of Ease, Perception of Risk and Perception of Trust in Interest in Using Mobile Banking.

Teguh, C. (2012). Factors affecting buying interest in guess online shop specialists. Management And Business Research Journal, 7(2), 147-60.

Wulandari, Putri,N., Novandriani,N. \& Moeliono,K. (2017). Business administration, and Telkom University: Analysis of the factors of using mobile banking services in Bandung. 139-49. 